\title{
Denizli Kenti Bazı Rekreasyon Alanlarının Görsel Peyzaj Kalitesi Açısından Değerlendirilmesi
}

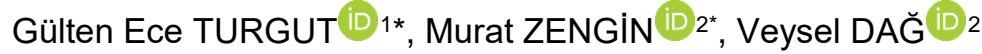 \\ ${ }^{1}$ Pamukkale Üniversitesi, Fen Bilimleri Enstitüsü, Denizli \\ ${ }^{2}$ Pamukkale Üniversitesi, Mimarlık ve Tasarım Fakültesi, Denizli \\ Geliş Tarihi (Received): 24.08.2021, Kabul Tarihi (Accepted): 24.09.2021 \\ $\square$ Sorumlu Yazar (Corresponding author*): mzengin@pau.edu.tr \\ (C) +902582962544 등 +902582962614
}

\section{ÖZ}

Bir alanın sunduğu doğal güzelliklerin yanında sahip olduğu görsel etkisi kullanıcıların alan deneyimlerini etkileyebilmektedir. Görsel peyzaj açısından kalitenin belirlenmesi, değerlendirilmesi, korunarak gelecek nesillerin kullanımına aktarılması ve kent ekolojisinin devamlıığının sağlanması günümüzde önem kazanmıştır. Bu kapsamda, peyzaj algısının görsel açıdan ele alındığı çalışmada, Denizli kentinde yoğun kullanılan 4 rekreasyon alanında (Çamlık Kent Ormanı, Teleferik/Bağbaşı Yaylası, Ornaz Vadisi Piknik Alanı ve Servergazi Mesire Alanı) 9 ortak kullanım tipi belirlenmiştir. Bu kullanımların görsel peyzaj kalitesinin değerlendirilmesinin yapılması amacıyla Denizli Kent Merkezi'ni oluşturan Merkezefendi ve Pamukkale ilçelerinde 271 kişi ile yüz yüze görüşme yoluyla anket çalışması yapılmıştır. Beğeni durumuna göre elde edilen sonuçlar her rekreasyon alanı ve kullanım tipi için ayrı ayrı olacak şekilde istatistiksel olarak değerlendirilmiştir. Değerlendirmeler sonucu Ornaz Vadisi Piknik Alanı bakımlı yüzey/alanlar $(\% 87,5)$ en fazla beğenilen kullanım tipi olurken, Teleferik/Bağbaşı Yaylası bakımlı yüzey/alanlar $(\% 8,4)$ en az beğenilen kullanım tipi olarak belirlenmiştir. Bu çalışmanın amacı Denizli kentindeki bazı rekreasyon alanlarının peyzaj yapısının algılanan görsel kalite ile ilişkili olup olmadığının ortaya konulmasıdır. Bu amaçla yapılan anket çalışması sonucu Denizli kenti rekreasyon alanları peyzaj yapısının algılanan görsel kalite ile ilişkili olduğu belirlenmiştir. Sonuç olarak kullanıcıların peyzaj algı ve tercihlerine göre görsel peyzaj kalite değerlendirmeleri dikkate alınarak, mevcut ve yapılacak rekreasyon alanları için öneriler geliştirilmiştir.

Anahtar Kelimeler: Denizli, görsel peyzaj, görsel peyzaj kalitesi, Pamukkale, rekreasyon

\section{Evaluation of Some Recreation Areas of Denizli City in terms of Visual Landscape Quality}

\begin{abstract}
In addition to the natural beauties offered by an area, its visual effect can affect the users' experience of the area. Determining and evaluating the quality in terms of visual landscape, protecting it and transferring it to the use of future generations and ensuring the continuity of the urban ecology have gained importance today. In this context, in the study, in which the perception of landscape is handled visually, 9 common usage types have been determined in 4 recreational areas (Çamlık Urban Forest, Cable Car/Bağbaşı Plateau, Ornaz Valley Picnic Area and Servergazi Recreation Area) that are used extensively in Denizli City. In order to evaluate the visual landscape quality of these uses, a survey was conducted through face-to-face interviews with 271 people in Merkezefendi and Pamukkale districts of Denizli City Center. The results obtained according to the level of appreciation were evaluated separately for each area and usage type. As a result of the evaluations, Ornaz Valley well-maintained surface/areas (87.5\%) were the most preferred usage type, while the Cable Car/Bağbaşı Plateau well-maintained surfaces/areas (8.4\%) were determined as the least favorite usage type. The aim of this study is to reveal whether the landscape structure of some recreation areas in Denizli is related to the perceived visual quality. As a result of the survey conducted for this


purpose, it was determined that the landscape structure of the recreation areas of Denizli city is related to the perceived visual quality. As a result, considering the visual landscape quality evaluations according to the landscape perception and preferences of the users, suggestions have been developed for the existing and future recreation areas.

Keywords: Denizli, visual landscape, visual landscape quality, Pamukkale, recreation

\section{GíRiş}

Günümüzde kentleşme ve sanayileşme hareketlerine sahne olan büyük kentlerimizin çoğunda nüfus artışına paralel olarak artan yapı yoğunluğu ve diğer plansız gelişmeler, yanlış yer seçimleri kentlerin kırsal alanlarla ilgisinin kopmasına neden olurken aynı zamanda, kentteki mevcut açık ve yeşil alanların azalmasına da yol açmaktadır (Yılmaz ve ark. 2003). Açık ve yeşil alanlar kentleşme hareketleri sonucunda doğa ile insan arasındaki kopmuş olan bağları onararak insandoğa ilişkisini yeniden kuracak kentsel mekanlardır (Önder, 1997).

Kentsel mekan tasarımında insanların yaşam kalitesinin artırılmasına yönelik çözümler üretilmesi esastır. Ancak, hızlı kentleşme nedeniyle açık ve yeşil alanlar üzerindeki baskılar artmakta ve kişi başına düşen yeşil alan miktarları yetersiz kalmaktadır. Bu kapsamda planlama ve tasarım çalışmalarında, kentsel yaşam kalitesinin artırılması açısından kültürel ve sosyal altyapının sağlıklı bir şekilde ele alınması gerekmektedir. Kentsel açık ve yeşil alanlar için oluşturulacak standartlarda kullanıcıların demografik yapısı, ekonomik yapısı, sosyo-kültürel yapısı, eğitim ve alışkanlıklar ile alanın konumu, büyüklüğü, mevcut bitki dokusu ve iklim özellikleri dikkate alınmalıdır.

Kent parkları sadece kentsel yeşil alan sisteminin hayati bir bileşeni değil, aynı zamanda bir bütün olarak bir şehir için peyzajı güzelleştiren önemli bir yeşil altyapı elemanıdır (Qi ve ark., 2017). Bu nedenle kent içerisinde bulunan doğal ve tarihi yapıların özelliklerini en iyi yansıtan örneklerinin yeşil alan sistemi içerisinde değerlendirilmesi yönünde çalışmalar yapılmalıdır (Dağ ve Mansuroğlu, 2020).

Dünya çapında, görsel estetik kalite su, toprak, madenler ve fosil yakıtlar gibi önemli bir doğal kaynaktır (Kane, 1981) ve insanın beden ve ruh sağlığı için değerlidir (Velarde ve ark., 2007; Kurdoglu ve Kurdoglu, 2010). Görsel estetik kalite kültürel mirasın korunması (Jessel, 2006) ve bir yerin turizm potansiyelinin artmasına katkı sağlar (Ewald, 2001). Bu nedenle, görsel estetik kalitenin korunması ve geliştirilmesi son yıllarda yaygın ilgi görmüştür (Wang ve Peng, 2011).
"Görsellik" nesne ve nesne gruplarının bulunduğu alan düzleminden ufuk düzlemine kadar görme duyusuyla algılanan görüntüler toplamının algılayıcılarda yarattığı duygusal ve mantıksal ifadelerin bütünü şeklinde tanımlanmaktadır (Temelli, 2008). Elinç ve Polat (2011)'e göre estetik kuramlarla açıklanabilen duyguların görüntülerdeki psikolojik ifadesi olarak tanımlanabilmektedir. Tüfekçioğlu (2008), bir kentin, çevrenin, görüntünün estetik olarak daha iyi olduğunu saptamanın yeterli olmadığını, esas önemli olanın ise ne kadar estetik olduğuna karar verilmesi gerektiğini belirtmiştir. Bazı araştırmacılara göre görsel kalite, nesnel değerler bağlamında güzellikle aynı anlama gelmekte; peyzaj değeri ise daha çok, bir peyzajdan kaynaklanan estetik tatminin öznel ve kişisel değerlendirmesi, insanlık ve peyzajın etkileşiminin bir ürünü olarak belirlenmektedir (Ak, 2010).

Genel olarak görsel kalite, insanların canlı/cansız obje veya çevresindeki manzaralara karşı estetik beğenilerini veya düşüncelerinin derecelerini gösteren bir kavramdır. Buna göre, insanlar yaşadıkları çevrede görsel önemi yüksek olan değerlere karşı daha dikkatli davranır. Güzellik kavramında insanların subjektif değerlendirmelerine karşın, estetik değer biçme obje veya manzaraların doğasında var olan bir takım özelliklere göre pozitif veya negatif yönde olabilmektedir. Çevresel psikolojiyle sıkı sıkıya bağlantılı olan görsel kalite kavramı, doğal veya doğal olmayan kaynakların oluşum biçimi, bu kaynakları kullanan kişilerin özellikleri (yaş, cinsiyet, sosyo-kültürel yapı, eğitim durumu, vb.) ve diğer çevresel etkenler (hava durumu, iklim, vb.) ile de ilişkilidir (Acar, 2003; Ak, 2010).

Wherreth (1996)'a göre, “Peyzaj kalitesi”, çevresel/ekolojik, sosyokültürel ve psikolojik faktörlerin geniş yelpazesini kapsayan bir terimdir ve akılda idealize edilmiş olan peyzaj ile kişinin gözlerinin önündeki peyzajın karşılaştırmasını anlatmaktadır (Gültürk, 2013). Bir peyzaj ile ilgili tercih ve değerlendirme çalışmasında peyzajın içinde bulunan herhangi bir objenin gözlemci üzerinde etkiye sahip karakteristik özellikleri, görüntünün bulunduğu alan ve çevreleyen peyzajın karakteristik özellikleri belirleyici rol oynamaktadır. Bu belirleyici rolün çerçevesini, peyzajdaki görsel tasarım elemanlarının, değişkenlerinin ve bunların yan yana 
geliş biçimlerinin de gözlemcinin üzerindeki etkisini çizmektedir (Kalın, 2004).

Görsel algıyı etkileyen faktörler arasında uyarıcının sahip olduğu anlam, kişinin uyarıcıyı daha önceden tanıması, kültür farklılıkları, zihinsel süreçlerin oluşturduğu düzen farklılıkları gibi etkenler gösterilmektedir. Görsel algı bu sayede bireye göre değişen bir olgu özelliği taşımaktadır. İnsanın bu zihinsel süreçte yaşadığı toplumun, kültürün, deneyimlerinin ve öğrenim düzeyinin etkisi oldukça büyüktür. Aynı zamanda da mekân algılamaya yönelik zihinsel düzen ise çevre ile etkileşimle gelişmektedir (Çağlayan ve ark., 2014).

Morgan (1984)'a göre, görsel algılamanın diğer algılamalardan farkı, en etkili ve en güçlü olmasıdır. Görsel algılamada insanlar, görme duyusu ile kazandıkları bilgileri anlayabilmek için, görsel uyarıcıları anlamlı bir şekilde örgütlemekte ve sınıflandırmaktadırlar (Çağlayan ve ark., 2014). Çevrenin algılanması; görme, işitme, duyma ve dokunma duyuları aracılığıyla gerçekleşmektedir ve bunların en önemlisi görme duyusudur. İnsanların duyusal girdisinin \%80'inden fazlası, görme duyusundan sağlanmaktadır (Porteous, 1996; Çakçı, 2007). Bir peyzaja ait görsel özellikler doğal, açık, çeşitli, gizemli, uyumlu, perspektif sunan, düzenli ve güven verici olduğu sürece alanın manzara güzelliği de o derecede yükselmektedir (Özhancı ve Yılmaz, 2011). Peyzaj görsel kalitesini değerlendirme tekniklerine başvurmak her zaman kolay olmasa da, bu kalite kırsal peyzaj çeşitliliğini korumak için muhafaza edilmesi gereken bir kaynak olarak düşünülmelidir (Angileri ve Toccolini, 1993).

Türkiye'de görsel peyzaj kalitesinin belirlenmesine yönelik Antakya (Bilgili, 2001), Karapınar-Konya (Önder ve Polat, 2004), farklı kent parkları örneğinde (yurtiçi ve yurt dışı 25 park) (Çakçı, 2007), Akçakoca Kıyı Bandı-Düzce (Ak, 2010), Kaçkar Dağları Milli Parkı (Acar ve ark., 2010), Tortum Şelalesi-Erzurum (Bulut ve ark., 2010), Erzurum Kenti (Irmak ve Yılmaz, 2010), Alanya-Antalya (Elinç ve Polat, 2011), Adalet ve İncilipınar Parkları-Denizli (Çelik, 2013),Tekirdağ Kent Merkezi Kıyı Şeridi (Gültürk, 2013), Aspendos-SillyonPerge (Antalya) yol güzergahında (Benliay ve ark., 2015), Düzce kent merkezi yaya alanlarında (Aytaş ve Uzun, 2015), Kıyıköy-Kırklareli (Kiper ve ark., 2017), Van Kenti yakın çevresindeki kıyı alanlarında (Aşur, 2017), Konyaaltı (Antalya) Kentsel yerleşim alanı (Oktay, 2017; Oktay ve Erdoğan, 2020) gibi farklı konu ve alanlarda yapılmış çalışmalar bulunmaktadır.
Bu çalışmada Denizli kenti rekreasyon alanlarının peyzaj yapısının algılanan görsel kalitesi ile ilişkili olup olmadığını ortaya koymak ve kullanıcıların peyzaj algı ve tercihlerine göre karşılıklı değerlendirmeler yaparak, mevcut rekreasyon alanları için önerilerin geliştirilmesi amaçlanmıştır.

\section{MATERYAL ve YÖNTEM}

\section{Materyal}

Denizli ili Ege Bölgesi'nin doğusunda, Büyük Menderes Havzasının üst kısmında yer alır. Denizli kenti doğudan Honaz Dağı (2571 m), Kuzeydoğudan Çökelez Dağı (1340 m), Kuzeybatıdan Doğu-Aydın Dağları Denizli kesimi (1700 m), Güneyden Akdağ (2449 m) ile sınırlandırılmış çöküntü bir havza içerisinde bulunmaktadır (Şekil 1). Denizli ili 354-2571 m rakıma sahip, $37^{\circ} 12^{\prime}-38^{\circ} 12^{\prime}$ kuzey paralelleri ile $28^{\circ} 30^{\prime}-29^{\circ} 30^{\prime}$ doğu meridyenleri üzerinde yer almaktadır. Denizli ili doğudan Burdur ve Afyonkarahisar, batıdan Aydın ve Manisa, güneyden Muğla, kuzeyden ise Uşak illeri ile sınır komşusudur. İ topraklarının \%47'si dağlar, \%28'i ovalar, \%23'ü platolar ve \%2'si yaylalardan oluşmaktadır. Akdeniz bitki örtüsünün hakim olduğu ilde karasal iklim tipinin özellikleri görülür.

Denizli kent merkezinde yer alan farklı büyüklük ve değişik fonksiyonlara sahip olan rekreasyon alanları Teleferik/Bağbaşı Yaylası (TBY), Çamlık Kent Ormanı (ÇKO), Servergazi Mesire Alanı (SMA), Ornaz Vadisi Park ve Piknik Alanı (OVP) çalışma alanı olarak seçilmiş olup, konumları Şekil 1'de gösterilmiştir. Çalışma alanı olarak seçilen rekreasyon alanlarının tamamı kentin güneyinde, Karcı Dağı eteklerinde, doğu-batı uzanımlı, eğimli dağlık alanlar ve vadi oluşumları üzerinde yer almaktadır. Bu açıdan şehir manzarasına hakim noktaları, zengin doğal bitki örtüsü ve serinletici temiz havası nedeniyle halk tarafından hemen hemen tüm yıl boyunca yoğun kullanılan rekreasyon alanları olma özelliği göstermektedir.

Çalışma alanı olarak Denizli kent merkezinde yer alan dört (4) adet rekreasyon alanının seçiminde;

a) Benzer kullanım yoğunluğu,

b) Görsel peyzaj kalite değerlendirmesi kapsamında ele alınan kullanım tiplerine (9 adet) sahip olması,

c) Rekreasyon alanlarının konumu ile erişilebilirlik durumları dikkate alınmıştır. 


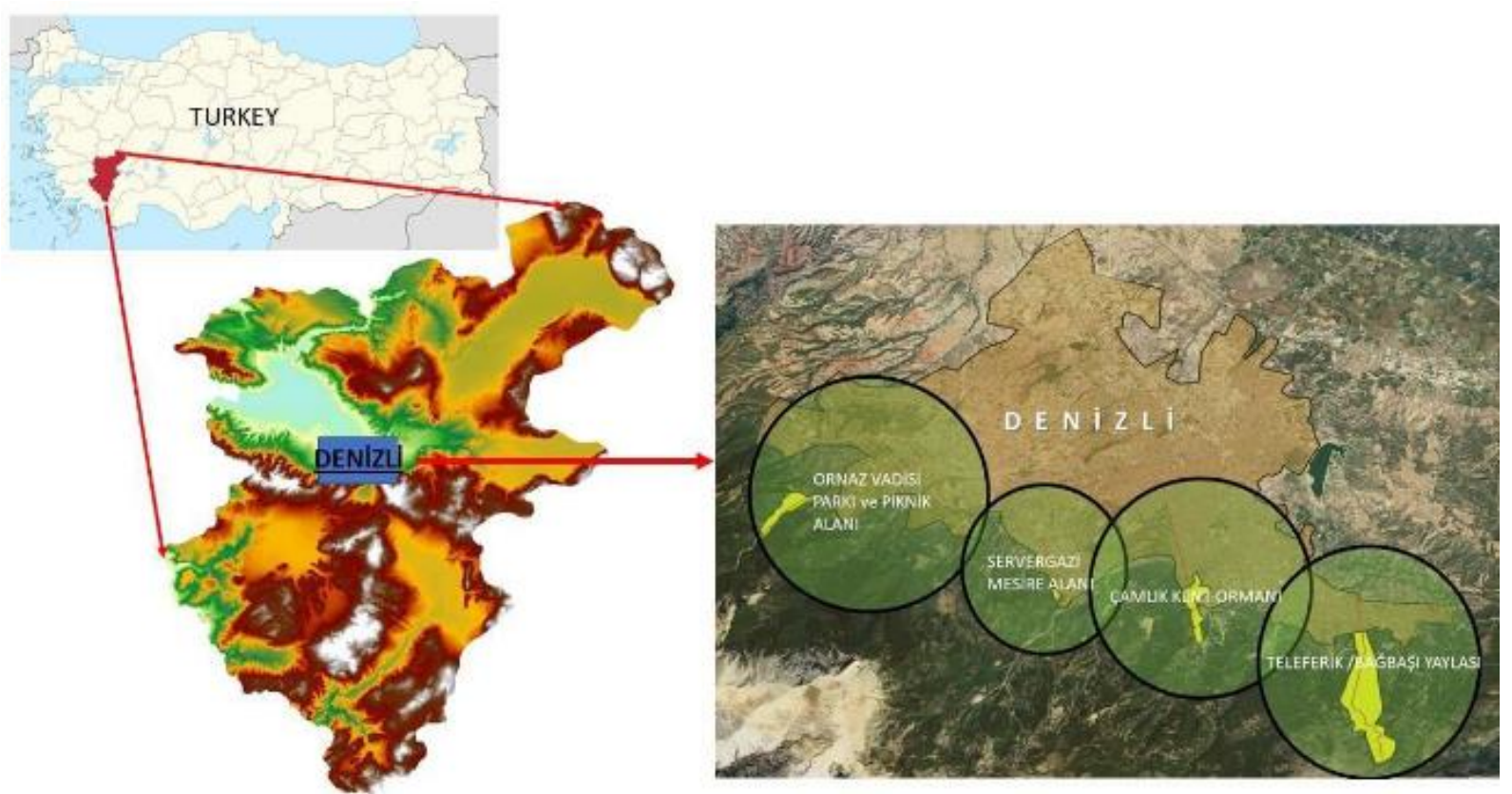

Şekil 1. Çalışma alanı konumu ve sınırları

\section{Yöntem}

Araştırmada, Denizli kentinde yerel yönetimler tarafından düzenlenerek halkın kullanımına sunulan rekreasyon alanlarında, kullanıcıların peyzaj algı ve tercihlerine göre, kulanım alanlarının (kullanım tiplerinin) görsel kalite açısından karşılıklı değerlendirmeleri yapılarak mekansal tipolojileri için öneri geliştirilmesinin amaçlandığı çalışma arazi ve ofis olmak üzere iki yönlü ve 5 aşamadan oluşmaktadır (Şekil 2). Araştırmada izlenen yöntem aşağıdaki şekilde sıralanabilir;

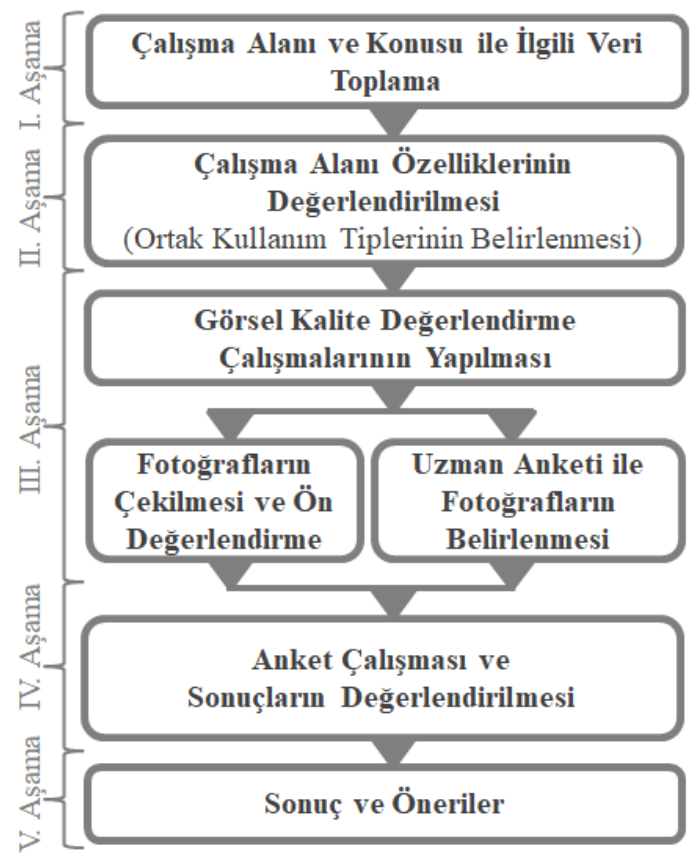

Şekil 2. Yöntem akış şeması

Çalışmanın ilk aşamasında, araştırma konusunun belirlenmesi ile konunun mesleki açıdan ve literatürdeki yeri ile önemi araştırılarak ilgili literatür taramaları yapılmıştır. Bu aşamada ayrıca çalışma alanı belirlenerek, Denizli kent halkının yoğun olarak kullandığı kente yakın mesafede $(4-10 \mathrm{~km})$ yer alan rekreasyon alanları seçilmiştir. Bu kapsamda Denizli kentinde Teleferik/Bağbaşı 
Yaylası (TBY), Çamlık Kent Ormanı (ÇKO), Servergazi Mesire Alanı (SMA), Ornaz Vadisi Park ve Piknik Alanı (OVP) çalışma alanı olarak seçilmiştir.

İkinci aşamada, çalışma alanı olan kentsel rekreasyon alanlarında görsel karşılaştırmaların yapılabilmesi için ortak kullanım alanları (kullanım tiplerinin) belirlenmiştir. Bu kapsamda belirlenen rekreasyon alanlarına yönelik yapılan arazi çalışmaları sonucu 4 rekreasyon alanının hepsinde ortak olan kullanım tipleri (Çocuk oyun alanları (ÇOA), Donatı elemanları (DE), Mimari yapılar (MY), Otopark alanları (OA), Piknik alanları (PA), Bakımlı yüzeyler/alanlar (BY), Su öğesi (SÖ), Yürüyüş yolları (YY), Bitişik manzara (BM) (Bu çalışmada, 9 kullanım tipinden en az 3 tanesinin aynı fotoğraf karesi içerisinde yer alması durumu bitişik manzara olarak tanımlanmıştır) belirlenmiştir.

Üçüncü aşamada, görsel kalite değerlendirme anket formunda kullanılmak üzere çalışma alanında yer alan ortak kullanım tiplerine ait fotoğrafların çekilmesi, sınıflandırılması ve gruplandırııması yapılmıştır. Çalışma alanını oluşturan rekreasyon alanlarındaki her bir kullanım tipi için en az 50-60 fotoğraf görüntüsü olacak şekilde, 18-105 mm lensli ve 24,1 milyon piksel çözünürlükteki Nikon D7100 Dijital Fotoğraf Makinesi ile 2018 Eylül ayında 12:00-13:00 saatleri arasında çekimler gerçekleştirilmiştir. Çalışmada, fotoğraf görüntülerinin algıyı etkilememesi için görsel değerlendirmede kullanılan görüntü alımı sırasında dikkat edilmesi gerekli konular literatüre dayalı olarak tespit edilerek fotoğraf çekimleri gerçekleştirilmiştir. Bu kapsamda, kontrolü güç olan "çekim saati", "ışık yönü", "hava koşulları" faktörleri eşit tutulmaya çalışılmıştır. Bakış açısı ve görüş uzaklığı göz önüne alınarak, görüntünün "derinlik", "kompozisyon", "mevcut fiziksel öğe", "çizgisel ve alansal grafik özelliklerin algıya etkisi" minimuma indirgenmiştir. Işık özelliklerinin görüntünün "çizgisel grafik özelliği" ve "derinliği" üzerinde oluşturduğu değişime dikkat edilmiştir. Göz seviyesinde fotoğraflama yapılmış, istenen fotoğraf tipine uygun olarak her rekreasyon alanında aynı mesafelerden alınan görüntüler kullanılmıştır. Dört rekreasyon alanında 9 kullanım tipi için toplam 1900 fotoğraf çekimi gerçekleştirilmiştir.

Rekreasyon alanlarına göre sınıflandırılan 1900 fotoğraf her bir kullanım tipi için araştırmacılar tarafından (2 kişi) "Scott's-Pr" yöntemiyle 4 fotoğrafa indirgenmiştir. "Scott's-Pr" yöntemi William A. Scott (1955) tarafından geliştirilen ve iletişim çalışmalarında nominal veriler için değerlendiriciler arası güvenirliği ölçen istatistiksel bir yaklaşım yöntemidir (Denklem 1). Bu kapsamda kullanılan formül aşağıda sunulmuştur.

$$
\pi=\frac{\operatorname{Pr}(a)-\operatorname{Pr}(e)}{1-\operatorname{Pr}(e)}
$$

Formüle göre;

$\operatorname{Pr}(\alpha)=$ Değerlendirici cevapların aldığı puan,

$\operatorname{Pr}(\mathrm{e})=$ Değerlendiricilerin cevapların toplamlarından elde edilen ortak oranı ifade etmektedir.

Yönteme göre, değerlendirmecilerin tüm verileri karşılıklı olarak aynı anda değerlendirme yapmaları istenir. Bu kapsamda alanı tanıyan ve bilen 2 kişi tarafından yapılan değerlendirmeler sonucu alanı en iyi temsil ettiği düşünülen görseller Evet/Hayır/Olabilir (yes/no/may be) şeklinde değerlendirilerek puanlandırılmıştır. Yapılan puanlama sonucu $\operatorname{Pr}(\alpha)$ ve $\operatorname{Pr}(e)(\operatorname{Pr}(\alpha)=(1+5+9) / 45=$ $0,333$ ve $\operatorname{Pr}(e)=0,369)$ değerleri bulunarak yukarıda verilen eşitlik aracılığıyla "Scott's- $P$ " $\quad(\pi=0,333-0,369 / 1$ $0,369=-0,059)$ sayısı hesaplanmıştır.

Elde edilen skorlardan kullanım tipine göre yöntem dahilinde sıfır ve sıfıra yakın olan ilk dört tanesi alanı en iyi temsil eden fotoğraf olarak seçilmiştir. Sonuçta dokuz (9) adet kulanım tipinin her biri için dörder (4) adet fotoğraf seçilmiştir. Yani her rekreasyon alanında 36 adet, dört (4) rekreasyon alanı için ise 144 adet fotoğraf 2 araştırmacı tarafından "Scott's-Pi" yöntemi ile belirlenmiştir.

"Scott's-Pl" yöntemi ile 4'e indirgenen fotoğraflar bu sefer her kullanım tipi için 5'li Likert Ölçeği (1-Hiç beğenmedim, 2-Beğenmedim, 3-Normal, 4-Beğendim, 5-Çok Beğendim) aracılığıyla Uzman Anket Değerlendirmesi ile alanı en iyi temsil eden tek bir fotoğrafa indirgenmiştir. Uzman Anket Değerlendirmesi'ne Pamukkale Üniversite Mimarlık ve Tasarım Fakültesi'nde görev yapan 11 akademik personel (5 Peyzaj Mimarı, 3 Mimar, 3 Şehir ve Bölge Plancı) katılım sağlamıştır. Uzman grubun görüntüleri sadece görsel boyutuyla değerlendirmeleri istenmiştir. Buna göre sınıf ortamına davet edilen uzmanlara ilgili rekreasyon alanının her bir kullanım tipi için 4'er tane fotoğraf aynı anda gösterilerek, bunların içinden "alanı en iyi temsil eden görüntüyü" seçmeleri istenmiş ve Likert Ölçeğine göre en çok puanı alan fotoğraf rekreasyon alanının ilgili kullanım tipini temsil eden görüntü olarak görsel kalite değerlendirme anketinde kullanılmıştır. Uzman anket değerlendirmeleri sonucunda rekreasyon alanlarında kullanım tiplerine göre seçilen ve kullanıcılar için Görsel Kalite Değerlendirme Anketinde yer alan 36 adet fotoğraf Şekil 3'de sunulmuştur. 
Denizli Kenti Bazı Rekreasyon Alanlarının Görsel Peyzaj Kalitesi Açısından Değerlendirilmesi

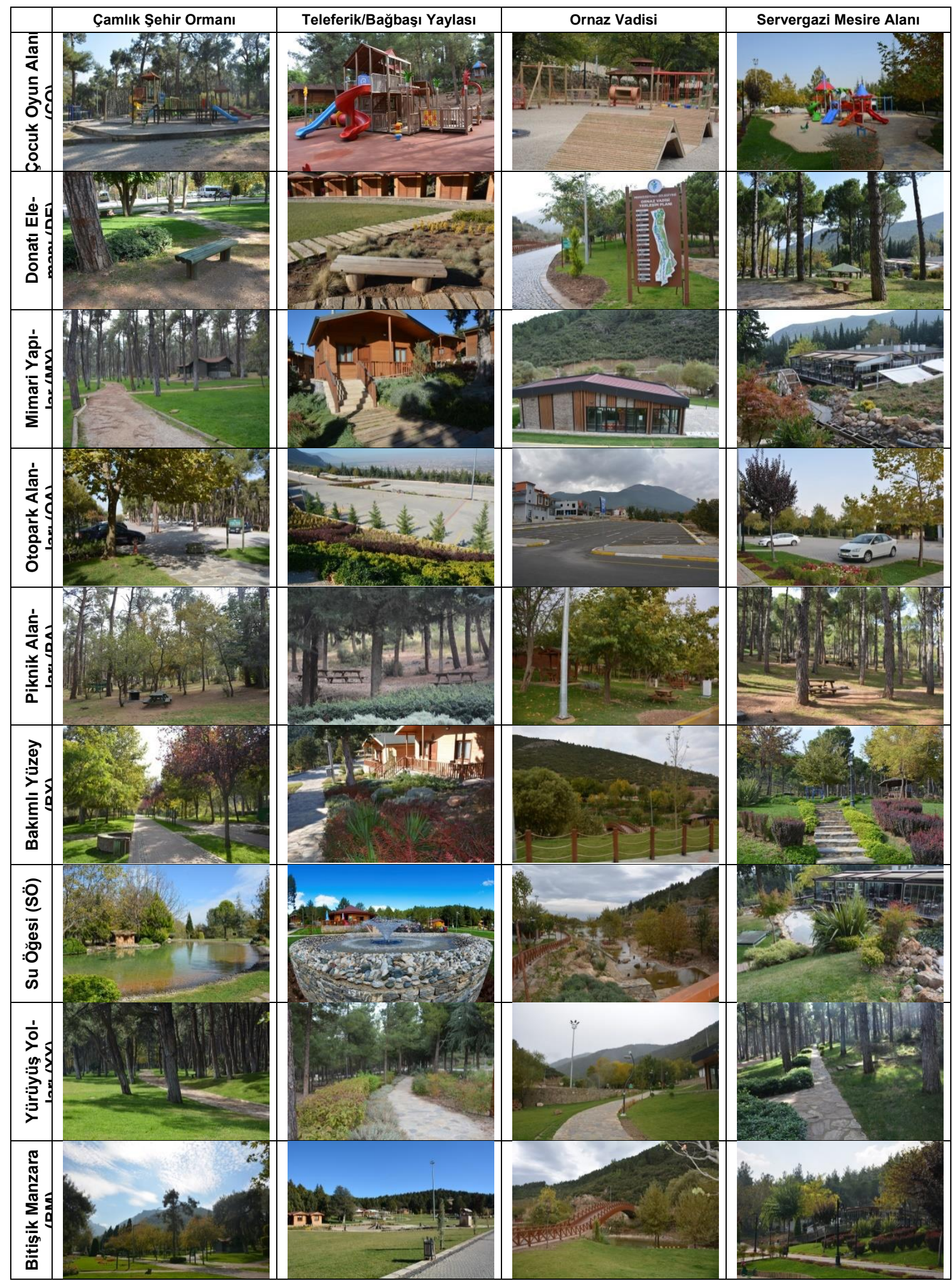

Şekil 3. Rekreasyon alanlarına göre Görsel Kalite Değerlendirme anketinde kullanılan görseller 
Araştırmanın dördüncü aşamasında görsel kalite değerlendirme anketi yapılmıştır. Denizli kent merkezini oluşturan Pamukkale (343. 290 kişi) ve Merkezefendi ilçe (295.699 kişi) nüfus verileri (TÜíK, 2019) dikkate alınarak (toplam 638.989 kişi) örneklem sayısı belirlenmiş ve Baş (2001) tarafından kullanılan aşağıdaki formüle göre (Denklem 2) hesaplanmıştır. Buna göre; \%5 hata payı ve $\% 90$ güven seviyesinde 271 kişi ile yapılacak anketin evreni temsil edeceği belirlenmiştir.

$$
\mathrm{n}=\frac{\mathrm{N} \cdot \mathrm{t}^{2} \cdot \mathrm{p} \cdot \mathrm{q}}{\mathrm{d}^{2} \cdot(\mathrm{N}-1)+\mathrm{t}^{2} \cdot \mathrm{p} \cdot \mathrm{q}}
$$

$\mathrm{N}=$ Evren büyüklüğü

$p=$ İncelenen olayın görülüş sıklığı $q=I n c e l e n e n$ olayın görülmeme sıklığı $(q=1-p)$

$\mathrm{t}=$ Belirli serbestlik derecesinde ve saptanan yanılma düzeyinde $t$ tablosunda bulunan teorik değer (\%95 güven aralığı için $\mathrm{t}=1,96$; \%99 güven aralığı için ise 2,59'dur)

d= Olayın görülüş sıklığına göre yapılmak istenen sapma olarak simgelenmiştir.

n=Örnekleme alınacak birey sayısı

Kullanıcı anketinde 4 rekreasyon alanında 9 adet kullanım tipi için 36 renkli fotoğraf kullanıcılara gösterilmiştir. Kullanıcı grubundan tek ölçüt üzerinde değerlendirme yapmaları istenmiştir. Bu ölçüt 4 rekreasyon alanında aynı kullanım tipi için 4 adet renkli fotoğraftan birini "beğenip beğenmediklerine göre" (5'li Likert Ölçeğinde) seçmeleri yönünde olmuştur. Kullanıcı grubunda beğeniyle ilgili olabildiğince tarafsız bir bakış açısı elde edebilmek için anket uygulamasında kadın erkek sayısına ve yaş grubunda ortalama bir dağılım olmasına özen gösterilmiştir.

Anketler vasıtasıyla elde edilen verilerin analizini yapmak ve bu analizden çıkan bulguları yorumlayabilmek için bilgisayar ortamına aktarılan veriler, SPSS 20 istatistik programı aracılığıyla değerlendirilmiştir. Katılımcıların beğenilerini gözlemleyebilmek ve karşılaştırmalı analizini yapabilmek için Wohlwill (1976), Okan (2006), Çakcı (2007) ve Çırak (2008) tarafından benzer çalışmalarda kullanılan ki-khare testi (Chi Square- $\chi^{2}$ ) yararlanılmıştır. Son aşamada ise görsel kalite değerlendirmesine ilişkin mekansal tipoloji önerileri geliştirilmiştir.

\section{BULGULAR}

\section{Katılımcıların Demografik Özellikleri}

Rekreasyon alanlarında görsel peyzaj kalite değerlendirmesinin yapıldığı araştırmada yöntem bölümünde açıklanan örneklem doğrultusunda yapılan anket çalışmasına 271 kişi katılım göstermiştir. Ankete katılanların $\% 50,9$ 'u erkek, \%49,1'i ise kadın olup, cinsiyete bağlı dağılımların eşit oranda olduğu söylenebilir. Katılımcıların \%56,8'i bekar \%43,2'si ise evlidir. Ar(Rete katılanların yarısı $(\% 49,2)$ Denizli'de doğup büyüdüğünü belirtirken, yarısının da $(\% 50,8)$ Ülkemizin diğer illerinden çeşitli nedenler ile Denizli'ye geldiği tespit edilmiştir. Ankete katılanların büyük çoğunluğunun $(\% 41,3)$ lise mezunu olduğu görülmektedir. Üniversite mezunu katıımcı oranı ise $\% 36,5$ olup, ilkokul $(\% 8,5)$, ortaokul $(\% 4,8)$, yüksek lisans $(\% 5,5)$ ve doktora $(\% 3,3)$ mezunlarından katılım sağlayanlar da bulunmaktadır. Ancak analizlerin güvenirliğinin sağlanması amacıyla değişkenlerde beklenen değerin 5 'ten küçük olduğu hücre sayısı, toplam hücre sayısının \%20'sinden fazla olması uygun görülmediğinden (Dağ, 2016) yüksek lisans ve doktora mezunları lisansüstü mezunu olarak birlikte değerlendirilmiştir (Tablo 1). Ankete katılanların gelir durumu incelendiğinde ailesi ile birlikte yaşadığı ve/veya öğrenci olduğu için doğrudan bir gelire sahip olmadığını belirtenler $\% 41,3$ oranındadır. 4001 TL ve üzeri gelire sahip bireyler $\% 20,3$ oranında, 3001-4000 TL gelire sahip olanlar $\% 7,7$ oranında, 2001-3000 TL gelire sahip olanlar $\% 13,7$ oranında iken, 1000-2000 TL gelire sahip bireylerin oranı \%17'dir. Ankete katılım gösteren en genç birey 16 $(\% 0,7)$ yaşında en yaşlı birey ise $88(\% 0,4)$ yaşında olup, katılımcıların yaş ortalaması 34,7'dir. Ankete katılanların yaş dağııımı ayrıntılı olarak Tablo 1'de gösterilmiştir. Ankete katılanların yaş gruplarından da anlaşılacağı üzere öğrencilerin oranı $(\% 37,3)$ daha yüksektir. Emekli $(\% 17,7)$, işçi $(\% 13,3)$, serbest meslek çalışanı $(\% 12,2)$, memur $(\% 9,2)$ sınıfından çalışanların bulunduğu katılımcılar arasında diğer grubundan özel sektör çalışanı, ev hanımı, çiftçi ve esnaf gibi meslek çalışanları $\% 5,5$ oranında bulunmaktadır. Anketin yapıldığı dönemde çalışmadığını belirtenlerin (işsiz) oranı da \%4,8'dir (Tablo 1). 
Tablo 1. Katılımcıların demografik özellikleri (\%)

\begin{tabular}{|c|c|c|c|c|c|c|c|}
\hline Eğitim Durumu & Oran & Gelir & Oran & Yaş Grupları & Oran & Meslek & Oran \\
\hline İlkokul & 8,5 & Yok & 41,3 & $16-24$ yaş & 39,5 & İşsiz & 4,8 \\
\hline Ortaokul & 4,8 & $1000-2000 \mathrm{TL}$ & 17,0 & $25-34$ yaş & 14,8 & Öğrenci & 37,3 \\
\hline Lise & 41,3 & $2001-3000 \mathrm{TL}$ & 13,7 & $35-44$ yaş & 19,9 & Memur & 9,2 \\
\hline Üniversite & 36,5 & $3001-4000 \mathrm{TL}$ & 7,7 & $45-54$ yaş & 11,4 & İşçi & 13,3 \\
\hline \multirow[t]{2}{*}{ Lisansüstü } & 8,8 & 4001 TL üzeri & 20,3 & $55-64$ yaş & 8,5 & Emekli & 17,7 \\
\hline & & & & 65 yaş ve üzeri & 5,9 & $\begin{array}{l}\text { Serbest Meslek } \\
\text { Diğer }\end{array}$ & $\begin{array}{l}12,2 \\
5,5\end{array}$ \\
\hline
\end{tabular}

\section{Kullanım Tiplerine Göre Rekreasyon Alanlarının Görsel Peyzaj Kalite Değerlendirme Sonuçları}

\section{a) Çocuk Oyun Alanı Kullanım Tipi}

Ankete katılanların Çamlık Kent Ormanı çocuk oyun alanı ile ilgili görüşleri sorgulandığında tüm değişken gruplar tarafından orta düzeyde beğenildiği görülmektedir. Erkekler \%29,0 oranında beğendim yanıtı verirken, kadınların ise \%17,3'ü beğendiklerini dile getirmişlerdir $(p<0,001)$. Evliler $(\% 41,9)$ bekarlar $(\% 38,3)$ ile Denizli'de doğanlar $(\% 34,8)$ diğer illerden gelenler $(\% 44,9)$ çoğunlukla orta düzeyde beğendiklerini belirtmişlerdir. Yaş grupları içerisinde 45-54 yaş grubu en yüksek oranla $(\% 25,8)$ istatistiksel olarak anlamlı beğendim yanıtı veren gruptur $\left(p=0,004 ; X^{2}=15,613\right)$. Lise ve üniversite mezunlarının aynı oranla orta $(\% 38,4)$, beğendim $(\% 18,2)$ ve çok beğendim $(\% 10,1)$ yanıtı vermeleri dikkat çekerken $(p<0,001)$, lisansüstü mezunlarının $\% 54,2$ 'si alandaki çocuk oyun alanını orta düzeyde beğendiklerini ifade etmişlerdir ( $\left.p=0,001 ; X^{2}=15,667\right)$. Meslek gruplarına göre beğeni durumu farklılık göstermektedir. Memurların \%40'ı orta düzeyde beğendim ve beğendim yanıtı verirken, \%16'sı çok beğendim, \%4'ü ise beğenmedim yanıtı vermişlerdir. Hiç beğenmedim yanıtı veren memur bulunmazken verilen yanıtların istatistiksel olarak anlamlı olduğu görülmektedir $\left(p=0,021 ; x^{2}=9,720\right)$. Herhangi bir gelire sahip olmadığını belirten bireyler Çamlık Kent Ormanı çocuk oyun alanı hakkında eşit oranla $(\% 18,8)$ beğenmedim ve beğendim görüşü paylaşmışlardır $\left(p<0,001 ; X^{2}=37,821\right)$. $4.001 \mathrm{TL}$ ve üzeri gelire sahip katılımcıların \%25,5'i alandaki çocuk oyun alanını beğendiğini, \%14,5'i ise beğenmediğini ifade etmiştir.

Teleferik/Bağbaşı Yaylası çocuk oyun alanının görsel peyzaj kalitesi değerlendirildiğinde katılımcı grupların yanıtlarının beğendim ve çok beğendim şeklinde yoğunlaştığı görülmektedir. Burada bulunan oyun gruplarının daha yeni olmasının rolü olduğu düşünülmektedir. Erkeklerin \%39,1'i beğendim, \%31,9'u çok beğendim $\left(p<0,001 ; \quad x^{2}=78,594\right)$ yanıtı verir iken, kadınların $\% 44,4$ 'ü beğendim, \%24,1'i çok beğendim yanıtı vermişlerdir ( $\left.p<0,001 ; X^{2}=74,782\right)$. Evlilerden çok beğendim yanıtı verenlerin oranı $(\% 31,6)$ bekarlardan daha yüksektir
(\%25,3). Benzer şekilde Denizli'de doğduğunu belirtenler $(\% 31,9)$ diğer illerden gelenlere $(\% 24,3)$ oranla daha yüksek düzeyde çok beğendim yanıtı vermişlerdir. 35-44 yaş grubu en yüksek oranla (\%50) beğendim yanıtı verirken $(p<0,001), 25-34$ yaş grubunun en yüksek düzeyde çok beğendim $(\% 35,0)$ şeklinde vermiş oldukları yanıtların istatistiksel olarak anlamlı olduğu görülmektedir $(p=0,014)$. İlkokul mezunları \%47,8 oranında çok beğendim $(p=0,005)$ yanıtı verirken, lise $(\% 46,4)$ ve üniversite mezunlarının $(\% 40,4)$ çoğunlukla beğendim $(p<0,001)$ şeklinde yanıtları dikkat çekmektedir. Iş̧̧ilerin en yüksek oranla beğendim $(\% 41,7)$ ve çok beğendim $(\% 41,7)$ şeklinde vermiş oldukları yanıtların da istatistiksel olarak anlamlı olduğu görülmektedir $(p=0,004)$. 1000-2000 TL gelire sahip grup en yüksek oranla çok beğendim $(\% 41,3)$ yanıtı verirken, $4001 \mathrm{TL}$ ve üzeri gelire sahip bireyler de $(\% 49,1)$ beğendim yanıtı vermişlerdir.

Ornaz Vadisi çocuk oyun alanını kadınların $\% 41,4$ 'ü çok beğenirken, erkeklerin \%41,3'ü beğenmektedir $(p<0,001)$. Evlilerin beğeni düzeyi bekarlardan yüksektir. Evlilerin \%37,6'sı çok beğendim, bekarların ise \%31,8'i çok beğendim yanıtı vermişlerdir $(p<0,001)$. Denizli'de doğduğunu ifade eden bireylerin \%36,3'ü Ornaz Vadisi çocuk oyun alanını çok beğendiğini, \%29,6'sı ise beğendiğini belirtirken, diğer illerden gelenlerin \%32,4'ü çok beğendiğini, \%39,7'si ise beğendiğini belirtmektedir $(p<0,001)$. Lise ve üniversite mezunlarının istatistiksel olarak anlamlı yanıtlar verdiği ve beğendim ve çok beğendim yanıtlarının çoğunlukta olduğu tespit edilmiştir. 25-34 yaş grubunda Ornaz Vadisi çocuk oyun alanını hiç beğenmedim diyen birey bulunmaz iken, bu yaş grubundan çok beğendim diyenlerin oranı \%40,0'dır. Ayrıca 3544 yaş grubundan çok beğendim diyenler $\% 40,7$ oranında iken, istatistiksel olarak anlamlı yanıtların alındığı diğer yaş grubu olan 16-24 yaş grubunun çoğunlukla $(\% 42,1)$ beğendim yanıtı verdikleri görülmektedir. Öğrencilerin \%41,6'sı beğendim, \%29,7'si çok beğendim yanıtı verirken, memurların \%44,0'ı beğendim, işçilerin $\% 47,2$ 'si çok beğendim, emeklilerin \%37,5'i de çok beğendim görüşünü paylaşmışlardır. 3001-4000 TL gelire sahip grup en yüksek oranla $(\% 52,4)$ çok beğendim yanıtı verirken, hiçbir gelire sahip olmayan bireylerin \%33,0'ı çok beğendim yanıtı vermişlerdir. 
Servergazi Mesire Alanı'ndaki çocuk oyun alanının görsel peyzaj kalitesi değerlendirildiğinde en az beğenilen çocuk oyun alanı olduğu görülmektedir. Bunun başlıca nedeni olarak çocuk oyun alanının her yerde bulunan tamamen plastik oyun gruplarından oluşması ön görülmektedir. Ayrıca bu çocuk oyun alanının belirli bir yaş grubu ile sınırlı olmasının da beğeni oranının düşük olmasında rol oynadığı tahmin edilmektedir. Ankete katılan kadınların \%36,8'i bu alandaki çocuk oyun alanını beğenmediğini ifade ederken, erkeklerin \%26,8'i beğendiğini belirtmişlerdir. Evli $(\% 26,6)$ ve bekarlar $(\% 26,6)$ çoğunlukla orta düzeyde beğendiklerini ifade etmişlerdir. Denizli'ye diğer illerden geldiğini belirtenlerin \%31,6'sı beğenmediğini belirtirken $(p<0,001)$, Denizli doğumluların vermiş oldukları yanıtların istatistiksel olarak anlamlı olmadığı $(p=0,222)$ görülmektedir. $16-24$ yaş $(\% 29,0)$ ve 35-44 yaş $(\% 31,5)$ grupları da çoğunlukla beğenmedim yanıtı vermişlerdir. Üniversite mezunlarının \%18,2'si hiç beğenmedim, \%31,3'ü beğenmedim, \%23,2'si orta düzeyde beğendim, \%19,2'si beğendim ve $\% 8,1$ 'i ise çok beğendim yanıtı vermiştir $\left(p=0,007 ; X^{2}=14,085\right)$. Lise mezunlarının ise $\% 29,5$ 'i orta düzeyde beğendiğini belirtirken, verilen yanıtların istatistiksel olarak anlamlı olduğu görülmektedir $\left(p=0,004 ; X^{2}=14,081\right)$. Öğrencilerin $\% 16,8$ 'i hiç beğenmediğini, \%28,7'si beğenmediğini, $\% 22,8$ 'i orta düzeyde beğendiğini, $\% 21,8$ 'i beğendiğini ve $\% 9,9$ 'u çok beğendiğini ifade etmişlerdir $(p=0,040$; $\left.X^{2}=10,040\right)$.

\section{b) Donatı Elemanları Kullanım Tipi}

Camlık Kent Ormanı donatı elemanlarını kadınların $\% 36,1$ 'i hiç beğenmediğini, $\% 23,3$ beğenmediğini, $\% 23,3$ 'ü orta düzeyde beğendiğini, \%13,5'i beğendiğini ve $\% 3,8^{\prime} i$ ise çok beğendiğini belirtmişlerdir $(p<0,001$; $X^{2}=38,992$ ). Bekarların \%37,7'si hiç beğenmediğini, $\% 22,7$ 'si beğenmediğini, \%23,4'ü orta düzeyde beğendiğini, \%11,0'ı beğendiğini ve \%5,2'si ise çok beğendiğini ifade etmişlerdir $\left(p<0,001 ; X^{2}=48,532\right)$. Denizli'de doğduğunu belirtenlerin Çamlık Kent Ormanı donatı elemanları hakkındaki görüşleri olumsuz (\%22,2'si hiç beğenmedim, \%26,7 beğenmedim) iken, diğer illerden gelenlerin de \%38,2'si alandaki donatı elemanlarını hiç beğenmediğini belirtmişlerdir. 16-24 yaş grubu \%43,0 oranla hiç beğenmedim yanıtı verirken, $35-44$ yaş grubu $\% 29,6$ oranla beğenmedim yanıtını çoğunlukla vermiştir. Ayrıca 35-44 yaş grubunun hiç beğenmedim, orta düzeyde beğendim ve beğendim yanıt oranları $(\% 22,2)$ eşit görülmektedir.

Çamlık Kent Ormanı donatı elemanları ile benzer özelliklere sahip Teleferik/Bağbaşı Yaylası bölgesinde bulunan ve katılımcılara gösterilen donatı elemanının da pek beğenilmediği tespit edilmiştir. Erkeklerin \%31,9'u ka- dınların ise \%30,8'i Teleferik/Bağbaşı Yaylası bölgesinde bulunan donatı elemanlarını hiç beğenmediklerini ifade ettikleri görülmektedir $(p<0,001)$. Bekarların $\% 36,4$ 'ü hiç beğenmedim, \%25,3'ü beğenmedim, $\% 22,1$ 'i orta düzeyde beğendim, $\% 9,1$ 'i beğendim ve $\% 7,1^{\prime} i$ ise çok beğendim yanıtı vermişlerdir $(p<0,001$; $\left.X^{2}=45,026\right)$.

Ornaz Vadisi donatı elemanlarının daha yeni ve renkli olmasının da etkisi ile diğer alanlardaki donatı elemanlarına oranla daha yüksek düzeyde beğenilmiştir. Erkeklerin \%29,0'ı Ornaz Vadisi donatı elemanı ile ilgili gösterilen görsel hakkındaki görüşlerinin çok beğendim şeklinde olduğu, kadınların ise \%33,1'inin aynı görsel hakkında beğendim şeklinde görüş paylaştığı dikkat çekmektedir $(p<0,001)$. Evli bireylerin $\% 27,4$ orta düzeyde ve çok beğendim şeklinde verdikleri yanıtların istatistiksel olarak anlamlı olduğu anlaşılmaktadır $(p<0,001$; $\left.X^{2}=29,368\right)$. Bekarların ise $\% 30,5^{\prime} \mathrm{i}$ beğendim, $\% 23,4$ 'ü orta düzeyde beğendim yanıtı vermişlerdir $(p<0,001$; $x^{2}=20,935$ ).

Servergazi Mesire Alanı donatı elemanları ile ilgili gösterilen görseldeki donatı elemanlarının farklı gruplar tarafından benzer oranlarla beğenildiği veya beğenilmediği görülmektedir. Oranların yakın olmasına bağlı olarak birçok grupta istatistiksel olarak anlamlı sonuçlar alınmamış olmasına rağmen, elde edilen sonuçların diğer alanlardaki donatı elemanlarına oranla Servergazi Mesire Alanı'ndaki donatı elemanlarının orta düzeyde beğenildiği söylenebilir. Alınan sonuçların alanın ve alandaki donatı elemanının diğer alanlardaki donatı elemanlarından farklı işleve sahip olması ile ilgili olabileceği düşünülmektedir. Evlilerin \%26,5’i Servergazi Mesire Alanı'ndaki donatı elemanını beğendiğini $(p=0,044)$, bekarların \%26,6'sı ise orta düzeyde beğendiğini $(p=0,031)$ ifade etmişlerdir. Herhangi bir gelire sahip olmayan bireylerin \%23,2'si bölgedeki donatı elemanlarını hiç beğenmediğini, $\% 16,1$ 'i beğenmediğini, $\% 30,4$ 'ü orta düzeyde beğendiğini, \%17,9'u beğendiğini ve $\% 12,5^{\prime} i$ ise çok beğendiğini belirtmişlerdir $\left(p=0,028 ; X^{2}=10,857\right)$.

\section{c) Mimari Yapılar Kullanım Tipi}

Çamlık Kent Ormanı mimari yapılarının görsel peyzaj kalitesi katılımcılardan genellikle beğendim (Erkek \%34,1; Kadın \%32,3) şeklinde görüş alınmışken, Teleferik/Bağbaşı Yaylası'ında bulunan mimari yapıların çok beğenildiği (Erkek \%44,9; Kadın \%49,6) tespit edilmiştir. Yapının doğal rengine yakın ahşap malzemeden olması ile yeni ve bakımlı olması katılımcıların beğenisini arttıran özellikler olarak görülmektedir. Ayrıca yapı ile çevre ilişkilerinde kullanılan malzemenin doğal (travers ve traverten) ve yapı ile uyumlu olmasının da beğeni düzeyini arttırıcı faktörler olduğu tahmin edilmektedir. 
Ornaz Vadisi'nde bulunan mimari yapılarında kullanıcılar tarafından çok beğenildiği tespit edilmiştir. Diğer alanlardaki mimari yapılardan farklı olarak traverten, ahşap malzeme ve cam gibi doğal malzemelerin birlikte kullanılarak inşaa edilmesi ve mimari özelliğinin de diğer yapılardan farklı olası beğeni düzeyini arttırıcı faktörler olarak gösterilebilir. Ayrıca yapının yeni ve bakımlı olması ile arkada dağ manzarasının bulunmasının da beğeni düzeyi üzerinde etkili olabildiği tahmin edilmektedir. Servergazi Mesire Alanı içerisinde yer alan mimari yapının açılır kapanır tavan ve yan cephelere sahip olması ve çevre ilişkilerinin güçlü olmasına bağlı olarak beğeni düzeyi yüksek sayılabilir. Ancak yapının doğala yakın alan içerisinde büyük yer kaplaması Ornaz Vadisi mimari yapısına oranla daha az beğenildiği görüşünü ön plana çıkarmaktadır.

\section{d) Otopark Alanı Kullanım Tipi}

Ankete katılan erkek $(\% 28,3)$ ve kadınların $(\% 28,6)$ benzer oranlarla Çamlık Kent Ormanı Rekreasyon Alanı otopark alanını hiç beğenmedikleri görülmektedir.

Teleferik/Bağbaşı Yaylası otoparkının kilitli parke taşı kaplama olması ve gölge alanının az olmasına rağmen, geniş bir otopark alanına sahip olması ile alanın manzara açısından önemli bir konumda olmasına bağlı olarak beğeni düzeyinin yüksek olduğu düşünülmektedir. Ankete katılan kadınların \%30,1'i otopark alanını orta düzeyde beğendiklerini, $\% 25,6$ 'sı beğendiklerini, $\% 24,1$ 'i ise çok beğendiklerini belirtmişleridir $(p<0,001$; $x^{2}=22,977$.

Ornaz Vadisi otopark alanı geniş olup, asfalt kaplıdır. Alan bitkisel ve yapısal gölgeleme elemanlarının varlığı açısından zayıf olup, bu durumun beğeni düzeyi üzerinde rol aldığı verilen yanıtlar incelendiğinde anlaşılmaktadır. Alanın pozitif ve negatif unsurları ankete katılanlar tarafından farklı şekillerde ele alındığından bu alandaki otopark ile ilgili yapılan istatistiksel analiz sonuçları incelendiğinde birbirine benzer ve yakın sonuçlar alınmıştır. Bu durum istatistiksel olarak anlamlı farklılıkların ortaya çıkmamasına yol açmıştır. Katılımcıların görüşleri incelendiğinde meslek gruplarından işçilerin vermiş oldukları yanıtların istatistiksel olarak anlamlı farklılıklar göstermektedir.

Ankete katılanların en çok beğendiği otopark alanı Servergazi Mesire Alanı otoparkıdır. Alanın bakımlı olması, peyzaj düzenlemeleri ile çevre yollardan ayrılmış olması ve otopark gölgeleme unsuru olarak bölgenin doğal bitki türlerinin seçilmiş olmasının önemli etken olduğu tahmin edilmektedir. Erkeklerin \%32,6'sı otopark alanını beğendiğini belirtirken, kadınların \%31,6'sı orta düzeyde beğendiğini belirtmişlerdir $(p<0,001)$

\section{e) Piknik Alanı Kullanım Tipi}

Çamlık Kent Ormanı piknik alanı Pinus brutia ormanı içerisinde yer almakta olup, ankete katılanlar tarafından orta düzeyin üstünde bir değerde beğenilmiştir. Herhangi bir geliri olmayan grubun $\% 30,4$ 'ü orta düzeyde beğendiğini, \%28,6'sı ise beğendiğini ifade etmişlerdir $\left(p=0,001 ; x^{2}=17,911\right) .4001 \mathrm{TL}$ ve üzeri gelire sahip olanlar ise orta düzeyde beğendim $(\% 32,7)$ ve beğendim $(\% 27,3)$ yanıtını vermişlerdir $\left(p=0,009 ; X^{2}=13,455\right)$.

Teleferik/Bağbaşı Yaylası piknik alanının katılımcılar tarafından beğenilmediği dikkat çekmektedir. Bunun en önemli nedeni diğer alanların çim kaplı olması ancak bu alanda zemin örtüsünün bulunmaması gösterilebilir. Ankete katılan erkeklerin \%26,8'i Teleferik/Bağbaşı Yaylası piknik alanını hiç beğenmediğini, \%26,1'i beğenmediğini, kadınların ise \%29,3'ü beğenmediğini, \%27,8'inin hiç beğenmediğini ifade ettikleri görülmektedir.

Ornaz Vadisi piknik alanı katılımcılar tarafından en fazla beğenilen piknik alanıdır. Öğrenciler $\% 47,5$ oranla beğendim yanıtı verirken, memurların beğendim yanıtı oranı \%52,0'dır. İşçilerin ise \%44,4'ü alanı çok beğen$\operatorname{dim}, \% 36,1^{\prime} i$ beğendim yanıtı vermişlerdir $(p=0,002$; $\left.x^{2}=15,333\right)$.

Servergazi Mesire Alanı'nda piknik alanı katılımcılar tarafından erkeklerin \%37,0'ı alanı beğendiğini, kadınların $\% 32,3$ 'ü orta düzeyde beğendiğini ifade etmiştir $(p<0,001)$. Lise $(\% 35,7)$, üniversite $(\% 34,3)$ ve lisansüstü mezunlarından $(\% 45,8)$ beğendim yanıtı verenlerin oranı yüksektir.

\section{f) Bakımlı Yüzeyler/Alanlar Kullanım Tipi}

Çamlık Kent Ormanı bakımlı alanlarının genellikle beğenildiği ve çok beğenildiği görülmektedir. Evli bireylerin $\% 44,4$ 'ü beğendim, \%40,2'si ise çok beğendim yanıtı vermiştir $\left(p<0,001 ; X^{2}=99,197\right)$. Bekarların ise \%37,0'। beğendim, \%34,4'ü çok beğendim yanıtı vermişlerdir $\left(p<0,001 ; X^{2}=88,078\right)$.

Teleferik/Bağbaşı Yaylası bakımlı alanlarının katılımcılar tarafından çok beğenildiği tespit edilmiştir. Buna göre ilkokul mezunları \%52,2 oranla, ortaokul mezunları $\% 61,5$ oranla çok beğendim yanıtı vermişlerdir. Lise mezunlarının \%38,4'ü eşit oranla beğendim ve çok beğendim yanıtı vermişlerdir $\left(p<0,001 ; X^{2}=68,000\right)$. Üniversite mezunlarını ise \%36,4'ü beğendim, \%32,3'ü çok beğendim şeklinde yanıt vermişlerdir $\left(p<0,001 ; X^{2}=19,900\right)$. Lisansüstü mezunlarının \%50'si beğendim yanıtı verirken, $\% 25$ 'i çok beğendim yanıtı vermişlerdir $(p=0,025$; $\left.x^{2}=9,333\right)$. 
Ornaz Vadisi bakımlı yüzey/alanlarının çok beğenildiği dikkat çekmektedir. Bir geliri olmayanlar \%60,7 oranında çok beğendim yanıtı verirken, $4001 \mathrm{TL}$ ve üzeri gelire sahip bireylerin \%50,9'u beğendim yanıtı vermişlerdir $(p<0,001)$.

Servergazi Mesire Alanı bakımlı yüzey/alanlarının da çok beğenildiği görülmektedir. Denizli doğumluların $\% 44,4$ 'ü, diğer illerden Denizli'ye gelenlerin $\% 57,4$ 'ü çok beğendim yanıtı vermişlerdir $(p<0,001)$. Benzer şekilde işsiz $(\% 69,2)$, öğrenci $(\% 58,4)$, işçi $(\% 47,2)$ ve emekli $(\% 47,9)$ 'lerin de çok beğendim şeklinde verdikleri yanıtlar çoğunluğu oluşturmakta ve sonuçlar istatistiksel olarak anlamlı görülmektedir. Tüm gelir gruplarından katılımcıların en yüksek oranda çok beğendim şeklinde verdikleri yanıtları istatistiksel olarak anlamlıdır.

\section{g) Su Öğesi Kullanım Tipi}

Çamlık Kent Ormanı'nda yer alan geniş yüzeye sahip gölet kullanıcılar tarafından beğenilmektedir. Su öğesinin sahip olduğu yansıma özelliği ve çevre ilişkilerinin beğenilmesinde etkili olduğu düşünülmektedir. Öğrencilerin \%34,7'si beğeniyorum yanıtı verirken, emeklilerin $\% 35,4$ 'beğeniyorum yanıtı vermiştir 3001-4000 TL gelire sahip olanların $\% 57,1^{\prime} i$ alandaki su öğesini beğendiğini ifade etmiştir $\left(p<0,001 ; X^{2}=20,667\right)$.

Yerden yükseltilmiş, doğal taş malzemeden inşaa edilmiş, hareketli süs havuzu şeklinde olan Teleferik/Bağbaşı Yaylası bölgesi su öğesinin ankete katılanlar tarafından beğenildiği ve çok beğenildiği dikkat çekmektedir. Illkokul mezunlarının \%47,8 oranla çok beğendim şeklinde verdikleri yanıtlar istatistiksel olarak anlamlıdır $\left(p=0,010 ; X^{2}=13,304\right)$. Lise mezunları da $\% 34,8$ oranla çok beğendim yanıtı vermişlerdir $\left(p<0,001 ; X^{2}=27,911\right)$. İşsiz olduğunu belirten katılımcıların \%61,5'i çok beğenmiştir $\left(p=0,018 ; X^{2}=10,077\right)$. 1000-2000 TL gelire sahip olanların $\% 54,3$ 'ü alandaki su öğesini çok beğenmiştir $\left(p<0,001 ; X^{2}=37,478\right)$.

Ornaz Vadisi'nde bulunan kaskatlı süs havuzu şeklindeki su öğesinin ankete katılanlar tarafından beğenildiği tespit edilmiştir. 16-24 yaş grubu \%30,8'i orta düzeyde beğendim, \%29,9'u ise beğendim yanıtı vermişlerdir $\left(p<0,001 ; x^{2}=26,037\right)$. 65 yaş ve üstü katılımcıların $\% 56,2$ 'sinin çok beğendim şeklinde vermiş oldukları yanıtların istatistiksel olarak anlamlı olduğu görülmektedir $\left(p=0,029 ; x^{2}=9,000\right)$.

Servergazi Mesire Alanı'ndaki su öğesi orta düzeyde beğenilmiştir. Geliri olmayanların \%5,4'ü hiç beğenmedim, $\% 14,3$ 'ü beğenmedim, \%29,5'i orta düzeyde beğendim, $\% 27,7$ 'si beğendim ve \%23,2'si çok beğendim yanıtı vermişlerdir $\left(p<0,001 ; X^{2}=22,732\right)$.

\section{h) Yürüyüş Yolları Kullanım Tipi}

Çamlık Kent Ormanı yürüyüş yolları genel olarak ankete katılanlar tarafından beğenilmektedir. Ankete katılan erkeklerin $\% 27,5$ 'i yürüyüş yollarını beğendiğini, $\% 26,1^{\prime}$ i ise çok beğendiğini belirtmektedir $\left(p=0,022 ; X^{2}=11,493\right)$. Evli bireylerin \%29,9'u çok beğendiğini, \%27,4'ü ise beğendiğini ifade etmiştir $\left(p<0,001 ; X^{2}=21,590\right)$.

Teleferik/Bağbaşı Yaylası, Ornaz Vadisi ve Servergazi Mesire Alanı yürüyüş yollarının kayrak taş kaplı olduğu ve Teleferik/Bağbaşı Yaylası alanı yürüyüş yollarının orta düzeyde beğenildiği görülmektedir. Yürüyüş yolları çevresindeki bitkilendirmelerin beğeni düzeyini etkilediği düşünülmektedir. Gelire sahip olmayanların \%33,9'u orta düzeyde beğendim, 1000-2000 TL gelire sahip olanlar \%34,8'i beğendim, 2001-3000 TL gelire sahip olanlar \%43,2'si orta düzeyde beğendim, 3001-4000 TL gelire sahip olanlar \%47,6'sı beğendim ve $4001 \mathrm{TL}$ ve üzeri gelire sahip olanlar $\% 38,2$ 'si orta düzeyde beğendim yanıtı vermişlerdir. Gelir grubuna göre verilen yanıtların istatistiksel olarak anlamlı olduğu görülmektedir.

Ornaz Vadisi yürüyüş yollarının çoğunlukla beğenildiği görülmektedir. Öğrenciler $(\% 40,6)$ ve emekliler $(\% 35,4)$ beğendim yanıtını, işçiler $(\% 38,9)$ ise çok beğendim yanıtını çoğunlukla vermişlerdir.

Servergazi Mesire Alanı yürüyüş yollarını evli bireyler $\% 36,8$ oranla beğendim, bekarlar $\% 29,2$ oranla orta düzeyde beğendim yanıtı vermişlerdir $(p<0,001)$.

\section{ı) Bitişik Manzara Kullanım Tipi}

Çamlık Kent Ormanı bitişik manzara açısından değerlendirildiğinde ankete katılanların beğendim ve çok beğendim şeklinde verdikleri yanıtlar çoğunluktadır. 25-34 yaş grubunun \%55,0'ı beğendim, 34-44 yaş grubunun $\% 48,1^{\prime} i$ beğendim, $45-54$ yaş grubunun ise $\% 54,8$ 'si çok beğendim yanıtı vermişlerdir $(p<0,001)$. 65 yaş ve üzeri grubun \%6,2'sinin hiç beğenmedim, \%37,5'inin beğendim ve \%56,2'sinin çok beğendim şeklinde vermiş oldukları yanıtların da istatistiksel olarak anlamlı olduğu dikkat çekmektedir $\left(p=0,047 ; x^{2}=6,127\right)$.

Teleferik/Bağbaşı Yaylası bitişik manzara kullanım tipini Denizli'de doğanlar \%30,4 oranla beğendim ve çok beğendim yanıtı vermişlerdir $\left(p<0,001 ; X^{2}=29,704\right)$. Diğer illerden Denizli'ye gelenlerin \%27,9'u eşit oranla orta düzeyde beğendim ve beğendim yanıtı vermişlerdir $\left(p=0,002 ; X^{2}=17,162\right)$.

Ornaz Vadisi bitişik manzara kullanım tipini kadın ve erkekler eşit oranla $(\% 40,6)$ çok beğendim yanıtı vermiş- 
lerdir $(p<0,001)$. Ankete katılan evlilerin \%39,3'ü bekarların ise \%41,6'sı çok beğendim yanıtı vermişlerdir $(p<0,001)$.

Servergazi Mesire Alanı'ndaki bitişik manzara kullanım tipini erkeklerin $\% 46,4$ 'ü kadınların ise $\% 50,4$ 'ü çok beğendiğini ifade etmişlerdir $(p<0,001)$. İlkokul $(\% 56,5)$, ortaokul $(\% 69,2)$, lise $(\% 55,4)$ ve üniversite $(\% 41,4)$ mezunları çok beğendim yanıtı vermişlerdir. Hiçbir işte çaıışmadığını belirtenler \%84,6 oranla çok beğendim yanıtı vermişlerdir $\left(p<0,001 ; X^{2}=15,385\right)$.

\section{SONUÇ}

Denizli Kent Merkezi'nde yer alan 4 rekreasyon alanındaki 9 kullanım tipine yönelik görsel peyzaj kalite değerlendirmesinin yapıldığı çalışmada elde edilen veriler ışığında tüm rekreasyon alanlarında kullanım tipine göre görsel peyzaj kalitesi değerlendirmesi sonucu en fazla beğenilen rekreasyon alanları ve kullanım tipleri (Tablo 2);

- Ornaz Vadisi Piknik Alanı: Kullanım Tiplerine göre Bakımlı Yüzey/Alanlar, Piknik Alanları ve Donatı Elemanları bakımından diğer rekreasyon alanlarına göre görsel açıdan en fazla beğenilmiştir.

- Bağbaşı Teleferik Yaylası: Kullanım Tiplerine göre Mimari Yapılar, Çocuk Oyun Alanları ve Otopark Alanları diğer rekreasyon alanlarına göre görsel açıdan en fazla beğenilmiştir.

- Servergazi Mesire Alanı: Kullanım Tiplerine göre, Bitişik Manzara ve Yürüyüş Yolları bakımından diğer rekreasyon alanlarına göre görsel açıdan en fazla beğenilmiştir.

- Çamlık Kent Ormanı: Kullanım tipine göre yalnızca Su Öğesi diğer rekreasyon alanlarına göre görsel açıdan en fazla beğenilmiştir.

Tablo 2. Görsel peyzaj kalite değerlendirmesi sonucu en fazla beğenilen rekreasyon alanları

\begin{tabular}{llc}
\hline \multicolumn{1}{c}{ Rekreasyon Alanı } & \multicolumn{1}{c}{ Kullanım Tipi } & Beğeni Oranı (\%) \\
\hline Ornaz vadisi Piknik Alanı & Bakımlı Yüzey/Alan & 87,5 \\
\hline Teleferik/Bağbaşı Yaylası & Mimari Yapılar & 81,9 \\
\hline Servergazi Mesire Alanı & Bitişik Manzara & 80,8 \\
\hline Ornaz vadisi Piknik Alanı & Piknik Alanı & 74,5 \\
\hline Teleferik/Bağbaşı Yaylası & Çocuk Oyun Alanı & 69,7 \\
\hline Çamlık Kent Ormanı & Su Öğesi & 58,0 \\
\hline Ornaz vadisi Piknik Alanı & Donatı Elemanları & 53,9 \\
\hline Teleferik/Bağbaşı Yaylası & Otopark Alanı & 50,2 \\
\hline Servergazi Mesire Alanı & Yürüyüş Yolu & 50,2 \\
\hline
\end{tabular}

Elde edilen verilerin ışığında tüm rekreasyon alanlarında kullanım tipine göre görsel peyzaj kalitesi değerlendirmesi sonucu en fazla beğenilmeyen rekreasyon alanları ve kullanım tipleri (Tablo 3);

- Teleferik/Bağbaşı Yaylası: Kullanım Tiplerine göre Piknik Alanları, Su Öğesi, Bitişik Manzara, Bakımlı Yüzey/Alanlar bakımından diğer rekreasyon alanlarına göre görsel açıdan beğenilmeyen alanlardır.

- Çamlık Kent Ormanı: Kullanım Tiplerine göre Donatı Elemanları, Otopark Alanları, Yürüyüş Yolları ve Mimari Yapılar bakımından diğer rekreasyon alanlarına göre görsel açıdan beğenilmeyen alanlardır.
- Servergazi Mesire Alanı: Çocuk Oyun Alanları bakımından diğer rekreasyon alanlarına göre görsel açıdan beğenilmeyen alan olmuştur.

- Ornaz Vadisi Piknik Alanı: Kullanım Tiplerine göre görsel açıdan beğenilmeme durumu diğer rekreasyon alanlarına göre bulunmamaktadır. 
Tablo 3. Görsel peyzaj kalite değerlendirmesi sonucu en az beğenilen rekreasyon alanları

\begin{tabular}{lll}
\hline \multicolumn{1}{c}{ Rekreasyon Alanı } & \multicolumn{1}{c}{ Kullanım Tipi } & Beğeni Oranı (\%) \\
\hline Teleferik/Bağbaşı Yaylası & Piknik Alanı & 55,0 \\
\hline Çamlık Kent Ormanı & Donatı Elemanları & 54,7 \\
\hline Çamlık Kent Ormanı & Otopark Alanı & 48,3 \\
\hline Servergazi Mesire Alanı & Çocuk Oyun Alanı & 39,5 \\
\hline Çamlık Kent Ormanı & Yürüyüş Yolları & 28,8 \\
\hline Teleferik/Bağbaşı Yaylası & Su Öğesi & 28,1 \\
\hline Teleferik/Bağbaşı Yaylası & Bitişik Manzara & 23,6 \\
\hline Çamlık Kent Ormanı & Mimari Yapılar & 16,2 \\
\hline Teleferik/Bağbaşı Yaylası & Bakımlı Yüzey/Alan & 8,4 \\
\hline
\end{tabular}

Günümüzde rekreasyon alanlarına olan talep ve intiyaç hızla artmaktadır. Özellikle küresel iklim değişikliği nedeniyle sıcaklıklarda seyreden ani artışlar, nüfus artışı, trafik yoğunluğu, hava-toprak-su kirliliği, plansız kentleşme, hızlı yapılaşma, asfalt ve beton yüzeylerin artması, gürültü vd., kentlerde yaşayan insanların rekreasyon alanlarını tercih etmeye değil, neredeyse zorunlu olarak bu alanları kullanmaya mecbur bırakmaktadır. Yoğun iş hayatı ve temposu, kentlerdeki hızlı yaşam ve yorucu kent atmosferinden kurtularak gezmek, dinlenmek, sosyalleşmek, spor yapmak, piknik yapmak eğlenmek için kullanılan rekreasyon alanları artık daha çok zinde kalmak, kaliteli nefes alabilmek, iklimsel konforu yakalamak, stresten uzaklaşmak, manzara seyretmek, ruh ve bedenen sakinleşmek gibi nedenlerle daha fazla tercih edilmeye başlanmış ve belli zamanlarda da yoğun kullanımlara sahne olmaktadır. Peyzaj Mimarlığı planlama ve tasarım yaklaşımları bağlamında rekreasyon alanlarının taşıma kapasitelerinin muhakkak hesaplanması ve uygulamaya aktarılması zorunluluk arz etmektedir. Özellikle günümüzde COVID-19 virüsü nedeniyle sosyal mesafenin korunması vb. diğer yaklaşımlarında mekansal tasarım çözümlemelerinde taşıma kapasitesi ile birlikte değerlendirilmesi oldukça önemli bir konu olmuştur. Mansuroğlu ve ark. (2021)'nın COVID-19 salgını ile insanların açık ve yeşil alanlarla ilişkilerini uzun süre kalıcı bir şekilde değiştirdiğini ortaya koymaları da durumu destekler niteliktedir.

Diğer taraftan, rekreasyon alanlarındaki kullanıcı profili, bu alanı kullananların intiyaçlarının belirlenmesinde önemli olup, kullanıcıların serbest zamanlarını değerlendirme şekli, bireysel özelliği, peyzaj algısı da intiyaçların şekillendirilmesinde dikkate alınması gereken konulardandır. Bu belirtilen fonksiyonların haricinde rekreasyon alanlarını çekici kılan ve tercih edilmesini sağlayan önemli özelliklerden biride kullanıcıların intiyaçlarına cevap verebilmesi ve doğal/kültürel peyzaj zenginliğidir.

Denizli kent merkezinde yoğun kullanılan farklı işlevlerdeki (kent ormanı, piknik alanı, mesire alanı) rekreasyon alanlarında yapılan tespit, fotoğraflama ve anket çalışmaları sonucu; uygulayıcılar ve yerel yönetimlere bazı öneriler geliştirilmiştir. Bunlar;

\section{Camlık Kent Ormanı;}

- Otopark alanlarının alansal olarak yetersizliği, güvenlik problemlerinin çözümlenmesi;

- Mimari Yapıların yeniden ele alınması, temizliği ve bakımı;

- Yürüyüş Yollarının stabil hale getirilmesi, düzeltilmesi, su birikintisi, çukur gibi sorunların tespit edilerek gerekli düzeltmelerin yapılması;

- Su Ögesi görsel peyzaj kalitesi en fazla beğenilen kullanım tipi olan ve halkın kendini rahat ve huzurlu hissettiği çamlık göletinin korunup geliştirilmesi önerilebilir.

\section{Servergazi Mesire Alanı;}

- Yeri ve konumunun yanında oldukça bakımlı ve düzenli olan mesire alanında kullanım tipi olarak Bitişik Manzara kullanım tipi kullanıcılar tarafından en fazla beğenilmiştir. Bitişik manzara olarak bu tez çalışmasında rekreasyon alanlarında ortak olan kullanım tiplerinden en az 3 kullanım tipinin aynı fotoğraf karesinde yer alması olarak tanımlanmıştır. Bu kapsamda Servergazi Mesire Alanı en az üç kullanım tipini alan içerisinde pek çok noktada sağlamış olduğunu görmekteyiz. Ayrıca dağ silueti, vadi ve ormanlık bir alan içinde yer alıyor olması da diğer peyzaj zenginliğidir.

- Elde edilen sonuçlara göre Çocuk Oyun Alanı kullanım tipi bakımından en fazla beğenilmeyen alan olmuştur. Alan içerisinde yalnızca bir alanda yoğunlaşan çocuk oyun alanlarının alternatiflerinin oluşturulması, mevcut çocuk oyun alanı otopark ve yol yakınında olduğu için yer seçiminin yeniden ele alınması önerilebilir. 
Ornaz Vadisi Piknik Alanı;

- Diğer tüm rekreasyon alanlarına göre kullanım tipleri bakımından Piknik Alanları, Donatı Elemanları, Bakımlı Yüzey/Alanları en fazla beğeniyi alan rekreasyon alanı olmuştur. Diğer kullanım tiplerinde de en fazla beğenilmeyen kullanım tipi bulunmayan tek rekreasyon alanı olması bakımından da ön plana çıkmaktadır. Bu durum rekreasyon alanı olarak yeni hizmete açılmış olması donatı elemanlarının kullanımlardan ya da iklimsel etkiler nedeniyle yıpranmamış olmasının katkısı olduğu düşünülmektedir. Mevcut beğeninin sürekliliği için alanda kullanılan malzeme ve donatıların bakım ve temizlik çalışmalarının sürekli yapılması öneri olarak belirtilebilir.

\section{Teleferik/Bağbașı Yaylası;}

- Çocuk Oyun Alanları, Mimari Yapılar, Otopark Alanları kullanım tipleri bakımından görsel peyzaj kalitesi en fazla beğeni alan alanları barındırdığı tespit edilmiştir. Alansal olarak büyüklüğü, topoğrafik açıdan eğimli bir yapı sergilemesi ve manzara seyri ise alana ayrı bir değer kattığı söylenebilir. Turizm amacıyla oluşturulan Teleferik ve iklimsel konfor açısından yüksek rakımlara ulaşılabilirlik alanın kullanımında önemli çekicilikler oluşturmaktadır.

- Donatı elemanları ve Bitişik Manzara kapsamında en fazla beğenilmeyen alan olmuştur. Bu kapsamda alan içerisindeki piknik masaları, oturma birimleri, aydınlatma, çöp kutusu, su gösterileri, süs havuzları gibi bazı donatı malzemelerinin arttırılması yerinde olacağı düşünülmektedir. Ayrıca özellikle piknik alanları için ayrılan makilik alanların tesviyesi, bakım ve düzenlemelerinin yapılmasının önemli olduğu düşünülmektedir.

Rekreasyon alanlarının görsel peyzaj açısından kalitesinde çekicilik, cazibe, doğallık, çeşitlilik, arazinin yapısı, şekli ve büyüklüğü, bakımlı ve düzenli, güvenli olmasının önemi büyüktür. Rekreasyon alanlarının planlama ve tasarım çalışmalarında bu özellikler dikkate alınarak gerekli harcama ve yatırımlar yapılmalıdır. Ayrıca Dağ ve Mansuroğlu (2020) kentin karakteristik özelliklerini yansıtan unsurların (traverten oluşumları, arkeolojik kalıntılar, doğal bitki türleri vb.) sistemli bir çalışma ile saptanması ve kentin simge alanlarından başlayarak tüm açık ve yeşil alan düzenlemelerinde kullanılması gerektiğini ifade etmişlerdir. Araştırmacılar kent kimliğinin oluşması ve ortaya çıkması açısından bu unsurların açık ve yeşil alanlarda kullanılacak kentsel donatı elemanlarına da yansıtılması gerektiğini belirtmişlerdir.

Çalışma sonucunda rekreasyon alanlarında kullanıcıların kişisel talep ve intiyaçları ile alanı deneyimlerken kar- şılaşmış oldukları olumlu ya da olumsuz durumların görsel fotoğraf puanlandırmalarına etki etmiş olduğu tespit edilmiştir. Örnek olarak, araçları ile rekreasyon alanlarına giremeyen, ücret ödeyen ya da yetersiz olduğu için park edemeyen kullanıcılar anket çalışmasında ilgili rekreasyon alanının otopark alanları kullanım tipi fotoğrafına da görsel açıdan düşük puan vermiştir. Başka bir örnek ise piknik alanına piknik malzemeleri ile gelen kullanıcılar piknik yapacakları yere en yakın noktada araçlarını park edememesi veya otopark alternatifinin yer almaması sonucu rekreasyon alanının görsel açıdan fotoğrafını düşük olarak değerlendirmiş olduğu belirlenmiştir. Doğal ve kültürel açıdan zengin, birbiri ile uyumlu mekan tasarımlarının algı ve tercih düzeyleri yüksek olabilmektedir. Sonuç olarak, Denizli kenti rekreasyon alanları peyzaj yapısının algılanan görsel kalitesi ile ilişkili ve önemli bir rolünün olduğu ortaya konulmuştur.

\section{TEŞEKKÜR}

Bu çalışma, "Rekreasyon Alanlarında Görsel Peyzaj Kalite Değerlendirmesi: Denizli Örneği” başlıklı Yüksek Lisans Tez çalışmasının verileri kullanılarak üretilmiştir.

\section{KAYNAKLAR}

Acar, C. (2003). Dağ ekosistemlerinde görsel kalite ve görsel kaynak yönetimi ekolojik ve görsel indikatörler. Kaçkar Dağları Milli Parkı Çevre Eğitimi Sunumu, Çamlıhemsin /Rize.

Acar, C., Kurdoğlu, B.Ç., Kurdoğlu, O., Acar, H. (2010). Public preferences for visual quality and management in the Kackar Mountains National Park (Turkey). International Journal of Sustainable Development \& World Ecology, 13(6): 499512.

Ak, M.K. (2010). Akçakoca kıyı bandı örneğinde görsel kalitenin belirlenmesi ve değerlendirilmesi üzerine bir araştırma. Doktora Tezi, Ankara Üniversitesi, Fen Bilimleri Enstitüsü, Peyzaj Mimarlığı Anabilim Dalı, 156s. Ankara.

Angileri, V., Toccolini, A. (1993). The assessment of visual quality as a tool for the conservation of rural landscape diversity. Landscape and Urban Planning, 24(1-4): 105-112.

Aşur, F. (2017). Van kenti yakın çevresi kıyı alanı örneğinde sulak alanlar ve görsel peyzaj kalite değerlendirmesi. Türk Tarım ve Doğa Bilimleri Dergisi, 4(4): 506-515.

Aytaş, İ., Uzun, S. (2015). Düzce kent merkezindeki yaya alanlarının görsel peyzaj kalitesinin belirlenmesi. Journal of the Faculty of Forestry Istanbul University, 65(1): 11-29.

Benliay, A., Soydan, O., Kayku, M. (2015). Aspendos- SillyonPerge bisiklet güzergahı örneğinde peyzaj görsel kalitesi ve peyzaj özelliklerinin değerlendirilmesi, Artium Derg., 3(1): 48-64.

Bilgili, C. (2001). Tarihi Antakya parkının rekreasyon alan kullanımı yönünden değerlendirilmesi ve geliştirilmesi üzerine bir araştırma. Yüksek Lisans Tezi. Mustafa Kemal Üniversitesi Fen Bilimleri Enstitüsü, 126s., Antakya-Hatay. 
Bulut, Z., Karahan, F., Sezen, I. (2010). Determining visual beauties of natural waterscapes: A case study for Tortum Valley (Erzurum/Turkey), Scientific Research and Essay, 5(2): 170-182.

Çağlayan, S., Korkmaz, M., Öktem, G. (2014). Sanatta görsel algının literatür açısından değerlendirilmesi. Eğitim ve Öğretim Araştırmaları Dergisi, 3(1): 160-173.

Çakcı, I. Y. (2007). Peyzaj planlama çalışmalarında görsel peyzaj değerlendirmesine yönelik bir yöntem araştırması. Doktora Tezi, Ankara Üniversitesi Fen Bilimleri Enstitüsü Peyzaj Mimarlığı Anabilim Dalı, Ankara.

Çelik, M. (2013). Kent parklarının görsel peyzaj algısının Denizli ili örneğinde irdelenmesi. Yüksek Lisans Tezi. Süleyman Demirel Üniversitesi, Fen Bilimleri Enstitüsü, s.164, Isparta.

Çırak, M. (2008). Mimaride biçimin görsel etkisi: tasarımcı hedefi ve kullanıcı üzerinden bir araştırma. Mimarlık Anabilim Dalı, Selçuk Üniversitesi, Konya.

Dağ, V. (2016). Pamukkale Özel Çevre Koruma Bölgesi'nde çevresel etkilerin değerlendirilmesi ve taşıma kapasitesinin belirlenmesi. Yüksek Lisans Tezi, Akdeniz Üniversitesi, Fen Bilimleri Enstitüsü, s.198, Antalya.

Dağ, V., Mansuroğlu, S. (2020). Turizm alanlarının kent kimliğine etkisi: Denizli kenti örneği. Atatürk Üniversitesi Sosyal Bilimler Enstitüsü Dergisi, 24(2): 589-604.

Elinç, H., Polat, A.T. (2011). Alanya Abdurrahman Alaettinoğlu Parkı kullanıcılarının demografik özellikleri ile parkın görsel kalitesi arasındaki ilişkiler. İnönü Üniversitesi Sanat ve Tasarım Dergisi, 1(3): 287 -296.

Ewald, K.C. (2001). The neglect of aesthetics in landscape planning in Switzerland. Landscape Urban Plann. 54 (1-4): 255-266.

Gültürk, P. (2013). Tekirdağ kent merkezi kıyı şeridinin görsel peyzaj kalitesi yönünden değerlendirilmesi. Yüksek Lisans Tezi, Namık Kemal Üniversitesi Fen Bilimleri Enstitüsü, Peyzaj Mimarlığı Anabilim Dalı, 121 s., Tekirdağ.

Irmak, M.A., Yılmaz, H. (2010). Farklı peyzaj karakter alanlarına göre doğal ve kültürel kaynak değerlerinin görsel analizi: Erzurum örneği. GOÜ, Ziraat Fakültesi Dergisi. 27(2): 45-55.

Jessel, B. (2006). Elements, characteristics and character-Information functions of landscapes in terms of indicators. Ecological Indicators, 6(1): 153-167.

Kalın, A. (2004). Çevre tercih ve değerlendirmesinde görsel kalitenin belirlenmesi ve geliştirilmesi: Trabzon sahil bandı örneği. Doktora Tezi, Karadeniz Teknik Üniversitesi Fen Bilimleri Enstitüsü, $221 \mathrm{~s}$., Trabzon.

Kane, P. S. (1981). Assessing landscape attractiveness: a comparative test of two new methods. Applied geography, 1(2): 77-96.

Kiper, T., Korkut, A. ve Topal, T.Ü. (2017). Görsel peyzaj kalite değerlendirmesi: Kıyıköy örneği. KSÜ Doğa Bilimleri Dergisi, 20(3): 258-269.

Mansuroğlu, S., Dağ, V., Kalaycı Önaç, A., Söğüt, Z., Birişçi, T. (2021). Approaches of landscape architects to applications for the use of open and green spaces in conditions of
Covid-19 pandemic. Megaron-90699; DOI: 10.14744/megaron.2021.90699.

Morgan, K.N. (1984). The emergence of the American landscape professional: John Notman and the design of rural cemeteries. The Journal of Garden History, 4(3): 269-289.

Okan Akın, N.O. (2006). İlköğretim görsel sanatlar eğitiminde estetik öğretimi. Doktora Tezi, Gazi Üniversitesi Eğitim Bilimleri Enstitüsü Güzel Sanatlar Eğitimi Anabilim Dalı Resim-iş Öğretmenliği Bilim Dalı, 159 s., Ankara.

Oktay, H.E. (2017). Bitkisel peyzaj tasarımlarının değerlendirilmesinde estetik: Antalya Konyaaltı bölgesi. Doktora Tezi, Akdeniz Üniversitesi Fen Bilimleri Enstitüsü, Peyzaj Mimarlığı ABD, 247 s., Antalya.

Oktay, H. E., Erdoğan, R. (2020). Bitkisel tasarımların formal (biçimsel) estetik model bağlamında değerlendirilmesi: Antalya Konyaaltı bölgesi. Mediterranean Agricultural Sciences, 33 (1): 51-57.

Önder, S. (1997). Konya kenti açık ve yeşil alan sisteminin saptanması üzerinde bir araştırma. Doktora Tezi, Ankara Üniversitesi Fen Bilimleri Enstitüsü, Peyzaj Mimarlığı Anabilim Dalı, 155 s., Ankara

Önder, S., Polat, A.T. (2004). Konya ili Karapınar ilçesinin ekoturizm yönünden görsel kalite değerlendirmesi ve swot analizi. S.Ü. Ziraat Fakültesi Dergisi, 18(33): 80-86.

Porteous, J.D. (1996). Environmental Aesthetics: ideas, politics and planning. Routledge, London.

Qi, T., Zhang, G., Wang, Y., Liu, C., Li, X. (2017). Research on landscape quality of country parks in Beijing as based on visual and audible senses. Urban Forestry \& Urban Greening, 26: 124-138.

Scott, W. (1955). Reliability of content analysis: The case of nominal scale coding. Public Opinion Quarterly, 19(3): 321325.

Temelli, M. (2008). Çukurova Üniversitesi Yerleşkesi örneğinde görsel etki değerlendirme çalışmalarına metodolojik bir yaklaşım. Yüksek Lisans Tezi, Çukurova Üniversitesi Fen Bilimleri Ens., 95 s., Adana.

Tüfekçioğlu, H.K. (2008). Tarihsel çevrede görsel peyzaj kalite değerlendirmesi İstanbul Yedikule örneği. Yüksek Lisans Tezi, İstanbul Üniversitesi Fen Bilimleri Enstitüsü, 136 s., İstanbul.

TÜİK (2019). Türkiye İstatistik Kurumu, Adrese Dayalı Nüfus Kayıt Sistemi, https://biruni.tuik.gov.tr/medas/?kn=95\&locale=tr (Erişim Tarihi: 10.06.2019).

Yılmaz, H., Yılmaz, S., Demircioğlu Yıldız, N. (2003). Kars kent halkının rekreasyonel talep ve eğilimlerinin belirlenmesi. Atatürk Üniversitesi Ziraat Fakültesi Dergisi, 34(4): 353360.

Wang, H.F., Peng, Q.H. (2011). Evaluation of scenic beauty of garden rock landscape. Journal of Central South University of Forestry \& Technology, 31(12): 124-132.

Wherret, J.R. (1996). Visualization techniques for landscape evaluation. http://bamboo.mluri.sari.ac.uk/ jo/ research.html. (Erişim Tarihi: 4.02.2018).

Wohlwill, J. F. (1976). Environmental aesthetics: The environment as a source of affect. In: Human behavior and environment, 37-86. 